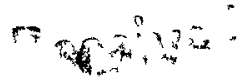

JEC 101991

\title{
INFORMATION MANAGEMENT PLAN
}

\author{
for the \\ NEVADA TEST SITE \\ GROUNDWATER CHARACTERIZATION PROJECT
}

by

Carol B. Thompson and Charles E. Russell

Water Resources Center

Desert Research Institute

University of Nevada System

Las Vegas, Nevada

prepared for

Environmental Restoration and Waste Management Division

Nevada Field Office

U.S. Department of Energy

Las Vegas, Nevada

December 1991

Publication \#45092 


\section{DISCLAIMER}

This report was prepared as an account of work sponsored by an agency of the United States Government. Neither the United States Government nor any agency Thereof, nor any of their employees, makes any warranty, express or implied, or assumes any legal liability or responsibility for the accuracy, completeness, or usefulness of any information, apparatus, product, or process disclosed, or represents that its use would not infringe privately owned rights. Reference herein to any specific commercial product, process, or service by trade name, trademark, manufacturer, or otherwise does not necessarily constitute or imply its endorsement, recommendation, or favoring by the United States Government or any agency thereof. The views and opinions of authors expressed herein do not necessarily state or reflect those of the United States Government or any agency thereof. 


\section{DISCLAIMER}

Portions of this document may be illegible in electronic image products. Images are produced from the best available original document. 


\title{
INFORMATION MANAGEMENT PLAN \\ for the \\ NEVADA TEST SITE \\ GROUNDWATER CHARACTERIZATION PROJECT
}

\author{
Water Resources Center \\ Desert Research Institute \\ University of Nevada System
}

Publication \#45092

\author{
prepared for \\ Environmental Restoration and Waste Management Division \\ Nevada Field Office \\ U.S. Department of Energy \\ Las Vegas, Nevada
}

December 1991

The work upon which this report is based was supported by the U.S. Department of Energy under Contract \#DE-AC08-90NV10845. 
This report was prepared as an account of work sponsored by the United States Government. Neither the United States nor the United States Department of Energy, nor any of their employees, makes any warranty, express or implied, or assumes any legal liability or responsibility for the accuracy, completeness or usefulness of any information, apparatus, product or process disclosed, or represents that its use would not infringe privately owned rights. Reference herein to any specific commercial project, process, or service by trade name, mark, manufacturer, or otherwise, does not necessarily constitute or imply its endorsement, recommendation, or favoring by the United States Government or any agency thereof. The views and opinions of authors expressed herein do not necessarily state or reflect those of the United States Government or any agency thereof.

This report has been reproduced directly from the best available copy.

Available to DOE and DOE contractors from the Office of Scientific and Technical Information, P.O. Box 62, Oak Ridge, TN 37831; prices available from (615) 576-8401, FTS 626-8401.

Available to the public from the National Technical Information Service, U.S. Department of Commerce, 5285 Port Royal Rd., Springfield, VA 22161. 


\section{CONTENTS}

INTRODUCTION 1

ORGANIZATIONS USING OR PROVIDING INFORMATION 1

INFORMATION TYPES

INFORMATION MANAGEMENT ACTIVITIES

Field Activities $\quad 2$

Sample Collection, Processing, and Tracking 3

Data Base Design and Management 4

Retrieval, Analysis, and Dissemination of Information 4

Archival and Cataloging of Data and Documentation 5 


\section{INTRODUCTION}

Information management plays a significant role in the Groundwater Characterization Project (GCP) because of its size and complexity. Information management's role is not defined by other aspects of the project (bottom-up approach). Instead, it shares complementary roles with research objectives and quality assurance (QA) to define how the project will be implemented (top-down approach). Information management serves as a backbone to the research effort by tying various project components together, from data collection through data analysis to the use of the information by researchers and program managers.

The information collected and analyzed from the Groundwater Characterization Project must be available to its users in a timely, cost-effective, and accurate manner. The quality and validity of these data are important to the overall Nevada Test Site program. The activities in this plan include:

- field activities;

- sample collection, processing, and tracking;

- data base design and management;

- retrieval, analysis, and dissemination of the data; and

- archiving and cataloging of the data and documentation.

The implementation of information management with respect to these activities is defined in this plan as strategies supplemented by Standard Operating Procedures (SOPs) to provide the details of each activity. The Quality Assurance Plan (QAP) seeks to assure that the information collected is of the highest possible quality permitted under current technology and science and is error-free.

\section{ORGANIZATIONS USING OR PROVIDING INFORMATION}

The following is a list of organizations that will either provide data to or require information from this project:

- U.S. Department of Energy, Headquarters;

- U.S. Department of Energy, Nevada Field Office;

- Desert Research Institute, University of Nevada System;

- Lawrence Livermore National Laboratory;

- Los Alamos National Laboratory; 
- Sandia National Laboratories;

- U.S. Environmental Protection Agency, Environmental Monitoring Systems Laboratory;

- Environmental Support Services Contractor (to be determined);

- Raytheon Services Nevada;

- Reynolds Electrical and Engineering Co., Inc.;

- United States Geological Survey;

- Schlumberger; and

- Atlas Wire Line.

\section{INFORMATION TYPES}

Several types of information will be collected and archived during the Groundwater Characterization Project. These include:

- historical data, such as aerial photographs, maps, and reports;

- field logs, including geophysical survey logs, calibration logs, field chain-of-custody records, well-construction diagrams, water chemistry, hydraulic tests, potentiometric data, and other field notes and forms;

- laboratory analytical data, including internal QA information and the environmental sample analysis results;

- QA audit data for field and laboratory activities; and

- documents, magnetic media, and microfiche.

\section{INFORMATION MANAGEMENT ACTIVITIES}

\section{Field Activities}

The objectives of the strategy for information management in field activities are:

- the information collected is of the highest quality and error-free;

- all pertinent and necessary information for a particular activity is recorded in a permanent form;

- strict adherence to SOPs and the QAP will be enforced; and

- all data generated in the field will be protected against accidental or intentional loss, damage, or alteration. 
The strategy is defined as follows:

- an SOP will be defined for any aspect of a field activity which affects the quality and preservation of information for this project;

- users of an SOP will be trained in its specifications;

- data collection forms will be prepared and used for any activity in which information is collected in the field;

- data from the collection forms will be entered into a computer within a specified time frame;

- identification of the data element is an inherent part of each data record;

- the software used for the data entry will perform certain consistency and range checks as the data are being entered and procedures will be defined when errors are detected; and

- the computerized information and original forms will be backed up and off-site storage will be available for one set of data or information according to defined procedures.

\section{Sample Collection, Processing, and Tracking}

The objectives of the strategy for information management related to sampling activities are:

- the information collected and tracked for the samples is of the highest quality and error-free;

- all pertinent and necessary information for a particular sample is recorded in a permanent form and every sample is appropriately labeled;

- strict adherence to SOPs and the QAP will be enforced; and

- all data relating to a sample will be protected against accidental or intentional loss, damage, or alteration.

The strategy is defined as follows:

- an SOP will be defined for any aspect of a sample-related activity which affects the quality and preservation of information for this project;

- users of an SOP will be trained in its specifications;

- data collection and chain-of-custody transfer forms will be prepared and used for any sample - related activity defined in these SOPs; 
- identification of the data element is an inherent part of each data record;

- data from these forms will be entered into a computer for storage and analysis;

- the software used for the data entry will perform certain checks as the data are being entered and procedures will be defined when errors are detected; and

- the computerized information and original forms will be backed up and off-site storage will be available for one set of information, data, and forms according to defined procedures.

\section{Data Base Design and Management}

The objectives of the strategy for this aspect of information management are:

- the design allows for some flexibility for future information management needs;

- the design and management of the information system should reflect the project's and users' needs for data integrity, accessibility, and timeliness;

- strict adherence to SOPs and the QAP will be enforced; and

- the data will be managed in accordance with computer security guidelines based on determinations of sensitivity, mission essentiality, and time criticality.

The strategy is defined as follows:

- responsibilities for the design and management of the data base will be clearly defined and assigned;

- the design will follow current information management technology;

- documentation of the design and subsequent changes will be logged;

- an SOP will be defined for any aspect of a data management activity which affects the quality and preservation of information for this project;

- users of an SOP will be trained in its specifications;

- logs that track activities relating to the implementation and management of the data base will be maintained; and

- project-related computer security internal assessments will be scheduled, accomplished, and documented. 


\section{Retrieval, Analysis, and Dissemination of Information}

The objectives of the strategy for use of the information are:

- information regarding the structure, types, and quality of the data is available to the user;

- the forms in which information is available are compatible with most users' immediate needs; and

- the methods by which information is available are user-friendly and provide for data security.

The strategy is defined as follows:

- more frequent formats for retrieval will be defined as macros for the users;

- a user's manual will be available and many options for retrieval will be menu-driven;

- retrievals performed by the information management staff will be logged;

- users will have access to parameters that define the quality of data they have retrieved;

- information disseminated to other organizations will contain pertinent documentation about the format and quality of the data; and

- data will be stored for read-only access and only data base management personnel will have access that allows changes to the data. All changes to data will be logged.

\section{Archival and Cataloging of Data and Documentation}

The objectives of the strategy for archival of information are:

- the information is to be protected for long-term efforts according to agreed upon disposition dates;

- the information is to be protected against accidental or intentional loss, damage, or alteration;

- the full scope and details of the information in the system will be available to the users; and

- documentation is considered as important a resource as the information in the system.

The strategy is defined as follows: 
- an SOP will be defined for any aspect of a data base management activity which affects the preservation of information and documentation for this project;

- users of an SOP will be trained in its specifications;

- logs that track activities relating to the implementation and management of the data base will be maintained; and

- a data catalog will be available and maintained according to the requirements of the project. 